\section{Sodium Chloride Absorption by the Urinary Bladder of the Winter Flounder \\ A Thiazide-sensitive, Electrically Neutral Transport System}

John B. Stokes,

with the technical assistance of

Ivan Lee and Melissa D'Amico

The Mount Desert Island Biological Laboratory, Salsbury Cove, Maine 04672; Laboratory of Epithelial Transport and Kidney Physiology, Department of Internal Medicine, University of Iowa, Iowa City, Iowa 52240 bstract. The urinary bladder of the winter flounder absorbs $\mathrm{NaCl}$ by a process independent of the transepithelial voltage. In contrast to most other epithelia which have a neutral $\mathrm{NaCl}$-absorptive system, the flounder bladder has a high transepithelial resistance. This feature simplifies analysis of the cellular transport system because the rate of ion transfer through the paracellular pathway is rather low. Experiments were designed to distinguish among three possible mechanisms of neutral $\mathrm{NaCl}$ absorption: (a) $\mathrm{Na} / \mathrm{K} / 2 \mathrm{Cl}$ cotransport; (b) parallel $\mathrm{Na} / \mathrm{H}$ and $\mathrm{Cl} / \mathrm{OH}$ exchange; $(c)$ and simple $\mathrm{NaCl}$ cotransport. A clear interdependency of $\mathrm{Na}$ and $\mathrm{Cl}$ for net absorption was demonstrated. $\mathrm{NaCl}$ absorption was not dependent on mucosal $\mathrm{K}$ and was minimally sensitive to loop diuretics. Thus a $\mathrm{Na} / \mathrm{K} / 2 \mathrm{Cl}$ transport system was unlikely. The mechanism was not parallel exchange as evidenced by insensitivity to amiloride and to 4,4'-diisothiocyano$2,2^{\prime}$-disulfonic stilbene, an inhibitor of anion exchange. In addition, inhibitors of carbonic anhydrase had no effect. Net absorption was almost completely abolished by hydrochlorothiazide $(0.1 \mathrm{mM})$. Its action was rapid, reversible, and effective only from the mucosal surface. Metolazone, a structurally dissimilar diuretic in the benzothiadiazide class had qualitatively similar actions. The

Dr. Stokes is an Established Investigator of the American Heart Association.

Received for publication 11 October 1983 and in revised form 6 December 1983.

J. Clin. Invest.

(C) The American Society for Clinical Investigation, Inc.

0021-9738/84/07/0007/10 \$1.00

Volume 74, July 1984, 7-16 mechanism of $\mathrm{NaCl}$ absorption in this tissue appears to be a simple interdependent process. Its inhibition by thiazide diuretics appears to be a unique feature. The flounder bladder may be a model for $\mathrm{NaCl}$ absorption in the distal renal tubule.

\section{Introduction}

There is now considerable evidence indicating that $\mathrm{NaCl}$ can be absorbed across the apical (luminal) membrane of certain epithelia by electrically silent processes (1-3). Such processes are currently believed to consist of three separate mechanisms for $\mathrm{NaCl}$ entry into the cell. One widely studied mechanism is that by which $\mathrm{Na}, \mathrm{K}$, and $\mathrm{Cl}$ are coupled. Examples of this process can be found in Ehrlich ascites tumor cells (4), the thick ascending limb of Henle's loop (5-7), the intestine of the winter flounder (8), and the distal nephron of the amphiuma $(9,10)$. The system is characterized by its dependence of all three ions to effect net $\mathrm{NaCl}$ transport and its inhibition by loop diuretics such as furosemide. The apparent stoichiometry is $1 \mathrm{Na} / 1 \mathrm{~K} /$ $2 \mathrm{Cl}$. A second mechanism for neutral $\mathrm{NaCl}$ absorption is parallel countertransport systems for $\mathrm{Na} / \mathrm{H}$ and $\mathrm{Cl} / \mathrm{OH}^{1}$ exchange. When the systems are operating at the same rate, net $\mathrm{NaCl}$ absorption occurs neutrally. These dual exchangers can be experimentally separated by selective inhibitors; amiloride in high concentrations (1 mM) inhibits $\mathrm{Na} / \mathrm{H}$ exchange (11), and stilbenes (inhibitors of anion exchange processes) inhibit $\mathrm{Cl} / \mathrm{OH}$ transport $(12,13)$. Epithelia where these parallel systems operate usually contain carbonic anhydrase and are sensitive to inhibitors of the enzyme. Examples of this system include the rat $(13,14)$ and rabbit $(15)$ small intestine, the cortical thick ascending limb of Henle's loop

1. In this article the anion exchange process will be designated as $\mathrm{Cl}$ / $\mathrm{OH}$ exchange because the system was nominally free of $\mathrm{CO}_{2}$. However, it is possible that this putative exchanger might utilize $\mathrm{HCO}_{3}^{-}$rather than $\mathrm{OH}^{-}$, especially in vivo where $\mathrm{HCO}_{3}^{-}$is more abundant. 
of the mouse (16), and the rabbit proximal tubule (17-19). The third mechanism by which neutral $\mathrm{NaCl}$ absorption occurs involves "simple" $\mathrm{NaCl}$ cotransport. Although this mechanism has been postulated for many epithelia, clear evidence of its existence involves, at a minimum, demonstration that the other two mechanisms are not present. This system is not so well characterized as are the first two, and thus the extent to which it contributes to neutral $\mathrm{NaCl}$ transport is not clear. There is some evidence that it may be present in the apical membrane of the Necturus gallbladder (20).

The urinary bladder of the winter founder is another example of an epithelium which possesses a neutral $\mathrm{NaCl}$ transport system. Renfro $(21,22)$ and Dawson and Andrew (23) have demonstrated that net $\mathrm{Na}$ and $\mathrm{Cl}$ absorption occur at approximately equal rates. Furthermore, net transport of either species is at least partially dependent on the presence of the other (22). A similar interdependence of $\mathrm{Na}$ and $\mathrm{Cl}$ absorption has been described in the trout urinary bladder (24). However, the flounder bladder differs from many other epithelia that absorb $\mathrm{NaCl}$ neutrally in at least one important aspect. Whereas other epithelia have a high transepithelial electrical conductance $\left(G_{\mathrm{T}}\right){ }^{2}$ typically 4-20 mS/cm ${ }^{2}$, the $G_{\mathrm{T}}$ of the flounder bladder is much lower, typically $0.2-1.5 \mathrm{mS} / \mathrm{cm}^{2}$. Tissues with $G_{\mathrm{T}}$ as low as this usually have a relatively low paracellular (passive) transport rate. In that this component represents only a fraction of the cellular (active) transport, the analysis of cellular transport is technically easier. Thus, this epithelium is well suited for a detailed evaluation of the nature of $\mathrm{NaCl}$ transport.

The results of the experiments demonstrate that the flounder urinary bladder has a combination of properties that have not been previously described. $\mathrm{NaCl}$ absorption is an interdependent process operating independently of mucosal $\mathrm{K}$. Furthermore, the system is selectively inhibited by thiazide diuretics.

\section{Methods}

Winter flounder, Pseudopleuronectes americanus, were obtained (by trawl) off the coast of Mount Desert Island, Maine, in June and July and maintained in flowing seawater tanks for up to $10 \mathrm{~d}$ before death. After cervical transection, the bladder ${ }^{3}$ was dissected free of the mesentary and the gonad, which surrounds the distal portion. The muscular layer remained attached to the epithelium. The bladders were opened longitudinally and pinned, mucosal side up, on a soft plastic sheet. A section

2. Abbreviations used in this paper: 8-Br-cAMP, 8-bromoadenosine 3',5'cyclic monophosphate; DIDS, 4,4'-diisothiocyano-2,2'-disulfonic stilbene; $g_{i}$, partial ionic conductance; $G_{\mathrm{T}}$, transepithelial conductance; HCTZ, hydrochlorothiazide; $I_{s c}$, short circuit current; $J_{i}$, unidirectional flux; $J^{\mathrm{ms}}$, mucosa-to-serosa flux; $J^{\mathrm{sm}}$, serosa-to-mucosa flux; $V_{\mathrm{T}}$, transepithelial voltage.

3. Technically speaking, this organ is a bladder insofar as it acts as a reservoir for urine. In contrast to urinary bladders of amphibia, the embryonic origin of the flounder bladder is mesodermal and is formed by the fusion of the mesonephric ducts (21). Therefore, it may be appropriate to consider this tissue an extension of the kidney. of the bladder was then mounted in concentric plastic rings as described by Dawson and Andrew (23). Depending on the size of the bladder, from one to four pieces of tissue (usually two) could be obtained. The rings, which exposed $1.25 \mathrm{~cm}^{2}$ of the bladder, were mounted in Ussing chambers and bathed with $10 \mathrm{ml}$ of solution on both mucosal and serosal surfaces. The solution was a modified Forster's solution containing (in millimoles/liter) $\mathrm{NaCl}, 140 ; \mathrm{KCl}, 2.5 ; \mathrm{CaCl}_{2}, 1.5 ; \mathrm{MgCl}_{2}, 1.0 ; \mathrm{N}-2$ hydroxyethylpiperazine- $N^{\prime}-2$ ethane sulfonic acid (Hepes), $7.5 ; \mathrm{Na}$ Hepes, 7.5; and glucose, 5 . Osmolality was $305 \pm 3$ and $\mathrm{pH}$ was 7.5. In solutions where $\mathrm{Cl}$ was removed, gluconate salts of $\mathrm{Na}, \mathrm{K}$, and $\mathrm{Ca}$ were substituted. The $\mathrm{SO}_{4}$ salt was used for $\mathrm{Mg}$. In solutions where $\mathrm{Na}$ was removed, choline $\mathrm{Cl}$ was substituted for $\mathrm{NaCl}$ and the buffer system was TrisHepes with a $\mathrm{pH}=7.5$.

The bladders were mounted in the chambers and gassed (and stirred) using room air and allowed to equilibrate at room temperature. Electrical measurements were made using two electrodes connected to each side of the chamber via polyethylene tubing containing an appropriate electrolyte solution in agar. One electrode measured transepithelial voltage $\left(V_{\mathrm{T}}\right)$ and the other passed current. The electrical conventions used for these studies were that $V_{\mathrm{T}}$ was measured with the serosal (basolateral) surface being ground. A positive current represents a flow of positive charge from serosa to mucosa. In most cases, $V_{\mathrm{T}}$ was clamped to $0 \mathrm{mV}$ by a voltage clamp made by the University of Iowa Bioengineering Department. $G_{\mathrm{T}}$ was determined from the change in the transepithelial current after brief $(0.5-1.0 \mathrm{~s})$ pulses of $10 \mathrm{mV}$ imposed every $100-200$ s. The series resistance of the solutions and the bridges were compensated before inserting the tissue so that the current deflection reflected only tissue conductance.

Preliminary evaluation of this tissue indicated that $G_{\mathrm{T}}$ was unstable with erratic behavior apparently corresponding to muscular contraction. Dawson and Andrew (23) had previously observed this phenomenon and reported that verapamil abolished the variations in $G_{\mathrm{T}}$ without affecting the short circuit current $\left(I_{\mathrm{sc}}\right)$ or the $\mathrm{NaCl}$ transport rate. Our experience was similar to theirs and consequently $50 \mu \mathrm{M}$ verapamil was constantly present in the serosal solution. In four experiments, verapamil had no effect on $I_{\mathrm{sc}}, G_{\mathrm{T}}$, or mucosa-to-serosa $\mathrm{Na}$ flux $\left(J_{\mathrm{Na}}^{\mathrm{ma}}\right.$, ranging from $5.83 \pm 0.96$ to $5.60 \pm 1.02 \mu \mathrm{M} / \mathrm{cm}^{2} \cdot \mathrm{h}$ ). With verapamil present, $J_{\mathrm{Na}}^{\mathrm{ms}}, I_{\mathrm{sc}}$, and $G_{\mathrm{T}}$ were stable for up to $8 \mathrm{~h}$.

Unidirectional ${ }^{22} \mathrm{Na}$ and/or ${ }^{36} \mathrm{Cl}$ fluxes were made by adding the appropriate isotope to one side of the chamber to reach an activity of $0.5-1.0 \mu \mathrm{Ci} / \mathrm{ml}$. Samples were made from the "hot" side every $20 \mathrm{~min}$ for mucosal-to-serosal (absorptive) fluxes and every $30 \mathrm{~min}$ for serosalto-mucosal fluxes. The "cold" side was sampled by removing $1 \mathrm{ml}$ and replacing it with an equal volume of solution. At the midpoint of each collection a small aliquot was taken from the hot side and diluted 100fold, and an aliquot was counted. At all times the isotope activity on the cold side was $<1 \%$ of that of the hot side. In general, two flux measurements were made for each period or experimental maneuver. The expression used to calculate the unidirectional flux $\left(J_{\mathrm{i}}\right)$ is: $J_{\mathrm{i}}$ $=(\mathrm{cpm}) /(\rho A t)$, where cpm is the counts per minute of the tracer appearing on the cold side during the flux period, $\rho$ is the specific activity of the tracer $(\mathrm{cpm} / \mu \mathrm{M}), A$ is the area $\left(1.25 \mathrm{~cm}^{2}\right)$, and $t$ is the time of collection. When ${ }^{22} \mathrm{Na}$ and ${ }^{36} \mathrm{Cl}$ fluxes were measured together, separate aliquots were obtained for gamma counting and liquid scintillation counting. Standard corrections for crossover were employed.

It soon became apparent that the $\mathrm{NaCl}$ transport rates varied widely, even between two pieces of the same bladder. Thus, the use of paired tissues to measure backflux (serosal-to-mucosal flux) separately was of questionable value. Instead, we used a protocol in which active transport was inhibited at the conclusion of the experiment. Dawson and Andrew 
Table I. Comparison of $J_{\mathrm{Na}}^{m s}$ and $J_{\mathrm{Cl}}^{m s}$ after Ouabain and Papaverine with $J_{N a}^{s m}$ and $J_{C I}^{s m}$

\begin{tabular}{llll} 
& Flux & & \\
& $\begin{array}{l}\text { Serosa-to-mucosa } \\
(n=9)\end{array}$ & $\begin{array}{l}\text { Mucosa-to-serosa after } \\
\text { ouabain and papaverine } \\
(n=6)\end{array}$ & $P$ \\
\hline$\mu M / \mathrm{cm}^{2} \cdot h$ & $\mu M / \mathrm{cm}^{2} \cdot h$ & NS \\
$J_{\mathrm{Na}}$ & 0.51 & 0.58 & \\
$J_{\mathrm{C} 1}$ & \pm 0.05 & \pm 0.11 & NS \\
& 1.41 & 1.71 & \\
\hline 0.13 & \pm 0.18 &
\end{tabular}

Concentration of papaverine in the mucosal solution, $0.5 \mathrm{mM}$; concentration of ouabain in the serosal solution, $0.1 \mathrm{mM}$. Na and $\mathrm{Cl}$ fluxes were determined simultaneously. $P$ values compare serosa to mucosa and mucosa to serosa fluxes of the same ion (by unpaired analysis).

(23) had previously shown that either papaverine or ouabain could inhibit net $\mathrm{Na}$ and $\mathrm{Cl}$ transport. In our preliminary experiments, we noted that ouabain did not always abolish the $I_{\mathrm{sc}}$ and never did so as quickly as papaverine. We thus elected to use these agents in combination (papaverine $0.5 \mathrm{mM}$ to mucosa and ouabain $0.1 \mathrm{mM}$ to serosa) to inhibit active transport. With this method we obtained an estimate of the passive flux for each tissue. The comparison of the inhibited mucosa-to-serosa flux and the serosa-to-mucosa flux for $\mathrm{Na}$ and $\mathrm{Cl}$ is depicted in Table I. For each experiment $\mathrm{Na}$ and $\mathrm{Cl}$ were determined simultaneously. The tissues were either exposed to ouabain and papaverine for $20 \mathrm{~min}$ (for mucosa-to-serosa flux) or untreated (for serosa-to-mucosa flux). The mean values for the $\mathrm{Na}$ fluxes are not different by paired analysis. The same is true for the $\mathrm{Cl}$ fluxes. Thus, $J^{\mathrm{ms}}$ following ouabain and papaverine is representative for $J^{\text {sm }}$ for that tissue.

In experiments where $\mathrm{Na}, \mathrm{K}$, or $\mathrm{Cl}$ concentrations were increased incrementally, they were added to the mucosal solution as a concentrated solution. At the end of the appropriate flux period, a small aliquot was taken for measurement of the actual concentration. $\mathrm{Na}$ and $\mathrm{K}$ were determined by flame photometry (Instrumentation Laboratory, Inc. Lexington, MA) and $\mathrm{Cl}$ by titration (Cotlove).

Unless stated otherwise, each agent was added in its powder form directly into the chamber. Many of the agents were tested in concentrations that approached their solubility: hydrochlorothiazide (HCTZ), metolazone, furosemide, and bumetanide are examples.

The following reagents were obtained from Sigma Chemical Co. St. Louis, MO: 4,4'-diisothiocyano-2,2'-disulfonic acid stilbene (DIDS), acetazolamide, 8-bromoadenosine 3',5'-cyclic monophosphate (8-BrcAMP), ouabain, papverine, HCTZ, and Hepes (both acid and Na salt) DIDS was prepared as a $10 \mathrm{mM}$ stock solution in ethanol and $100 \mu \mathrm{l}$ was added to the mucosal solution to make a final concentration of 0.1 $\mathrm{mM}$. In control experiments this amount of ethanol had no effect of $I_{\mathrm{sc}}, G_{\mathrm{T}}$, or $J_{\mathrm{Na}}^{\mathrm{ms}}$. Ouabain was prepared as a $10 \mathrm{mM}$ aqueous stock solution and 8-Br-cAMP was prepared as a $100 \mathrm{mM}$ aqueous stock solution. Amiloride was obtained from Merck Sharp \& Dohme (West Point, PA), furosemide from American Hoechst Corp. (Somerville, NJ), bumetanide from Hoffmann La Roche Inc, (Nutley, NJ), metolazone from Pennwalt Corp. (Philadelphia, PA), and verapamil from Knoll
Pharmaceutical Co. (Orange, NJ). Verapamil was prepared as a $50 \mathrm{mM}$ aqueous stock.

Results are presented as mean \pm standard error. Statistical analysis was by analysis of variance, or paired or unpaired $t$ test as appropriate. For paired or unpaired comparisons, a significant difference was concluded when $P<0.05$. For experiments where multiple paired comparisons were made, a significant difference was concluded when $P<0.025$.

\section{Results}

To ascertain that, under the present experimental conditions, $\mathrm{Na}$ and $\mathrm{Cl}$ transport were interdependent, experiments were conducted where the mucosal solution was nominally $\mathrm{Na}$ or $\mathrm{Cl}$-free initially and the appropriate tracer flux was measured. Fig. 1 demonstrates that by raising $\mathrm{Cl}$ concentration from 0.5 to 6 and then to $20 \mathrm{mM}, J_{\mathrm{Na}}^{\mathrm{ms}}$ increased from $0.59 \pm 0.13$ to $1.61 \pm 0.33$ to $2.29 \pm 0.45 \mu \mathrm{M} / \mathrm{cm}^{2} \cdot \mathrm{h}$. Subsequent addition of ouabain and papaverine reduced $J_{\mathrm{Na}}^{\mathrm{ms}}$ to $0.65 \pm 0.09 \mu \mathrm{M} / \mathrm{cm}^{2} \cdot \mathrm{h}$, indicating that the increase observed by the addition of $\mathrm{Cl}$ was owing to active transport. The periods are different (by analysis of variance) and each period is different from the previous period by paired analysis. Changes in $I_{\mathrm{sc}}$ and $G_{\mathrm{T}}$ were variable and were not significant.

Fig. 2 demonstrates the effect of raising [Na] from 2 to 8 $\mathrm{mM}$ and then to $20 \mathrm{mM}$ to $J_{\mathrm{Cl}}^{\mathrm{ms}}$. These maneuvers caused $J_{\mathrm{Cl}}^{\mathrm{ms}}$ to increase from $1.12 \pm 0.22$ to $5.50 \pm 1.58$ to $7.38 \pm 1.95 \mu \mathrm{M} /$ $\mathrm{cm}^{2} \cdot \mathrm{h}$. Addition of ouabain and papaverine caused $J_{\mathrm{C}}^{\mathrm{ms}}$ to fall to $2.69 \pm 0.50 \mu \mathrm{M} / \mathrm{cm}^{2} \cdot \mathrm{h}$. As was true for the previous experiment, each value was significantly different from the previous one. Thus, there appears to be codependence on $\mathrm{Na}$ and $\mathrm{Cl}$ to effect net transport.

$\mathrm{Na} / \mathrm{K} / 2 \mathrm{Cl}$ cotransport. In a number of epithelia known to have interdependent $\mathrm{Na}$ and $\mathrm{Cl}$ transport, there has been recent

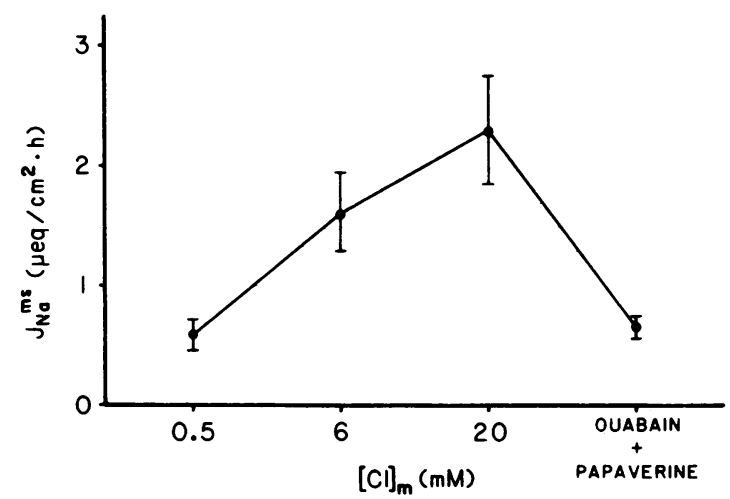

Figure 1. Effect of mucosal $\mathrm{Cl}$ concentration on $J_{\mathrm{Na}}^{\mathrm{ms}}$. $\mathrm{Cl}$ was added (as $\mathrm{NaCl}$ ) to mucosal solution which contained a nominally $\mathrm{Cl}$-free (gluconate) solution. $\mathrm{Cl}$ concentration on abscissa represents measured values at the end of the flux period. Bars represent SEM. Each value is significantly different from the previously measured value. Ouabain and papaverine value represents passive component of the unidirectional flux $(n=8)$. 


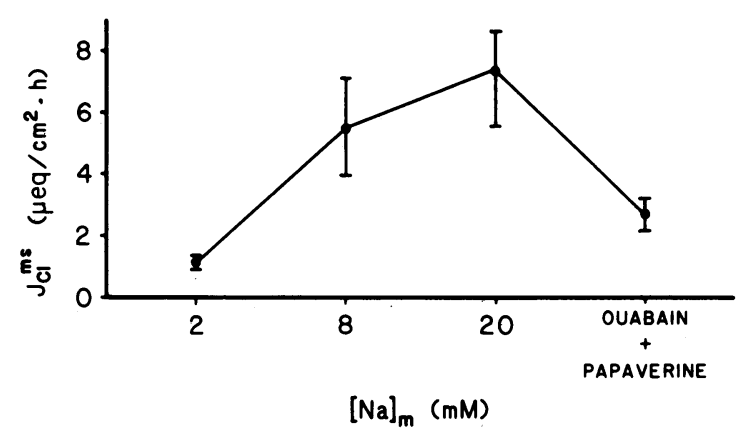

Figure 2. Effect of mucosal Na concentration on $J_{\mathrm{Cl}}^{\mathrm{ms}}$. Na was added (as $\mathrm{NaCl}$ ) to mucosal solution which contained a nominally Na-free (choline) solution. Bars represent SEM. Each value is significantly different from the previously measured one $(n=4)$.

evidence indicating that mucosal $K$ is also required. The $K$ dependency of $\mathrm{NaCl}$ transport in flounder bladder was tested in a manner similar to that described for the previous experiments. Several precautions were taken to insure that all $\mathrm{K}$ was removed from the mucosal solution. The mucosal surface was washed with $\mathrm{K}$-free solution five times and, $2.5 \mathrm{mM} \mathrm{BaCl} \mathrm{m}_{2}$ was added to the mucosal solution to inhibit $\mathrm{K}$ secretion. Dawson and Andrew (25) have reported that when a $I_{s c}$ is present, it represents $\mathrm{K}$ secretion and can be blocked completely with mucosal $\mathrm{Ba}$. The present results confirmed that the spontaneous $V_{\mathrm{T}}$ was lumen positive and that the spontaneous $I_{\mathrm{sc}}$ was also positive. Furthermore, mucosal $\mathrm{BaCl}_{2}$ reduced the $I_{\mathrm{sc}}$ to 0 . In order to determine whether $\mathrm{BaCl}_{2}$ affected $\mathrm{NaCl}$ absorption, 5 $\mathrm{mM} \mathrm{BaCl} 2$ was added to the mucosal solution of four tissues and $J_{\mathrm{Na}}^{\mathrm{ms}}$ was measured. $\mathrm{BaCl}_{2}$ had no effect on $J_{\mathrm{Na}}^{\mathrm{ms}}$ (decrease from $5.60 \pm 1.02$ to $5.13 \pm 0.72 \mu \mathrm{M} / \mathrm{cm}^{2} \cdot \mathrm{h}$ ). Thus, $2.5 \mathrm{mM} \mathrm{BaCl}$ was continuously present in the mucosal solution of the experiments that examined the $\mathrm{K}$ dependency. Table II displays the effect of increasing mucosal $\mathrm{K}$ concentration on $J_{\mathrm{Na}}^{\mathrm{ms}}$ and $J_{\mathrm{Cs}}^{\mathrm{ms}}$ (determined in separate tissues). There was no significant effect on either flux. Ouabain and papaverine inhibited these fluxes indicating the component of active transport.

Because the loop diuretics inhibit the $\mathrm{Na} / \mathrm{K} / 2 \mathrm{Cl}$ transport process $(4,6,8,9,26)$, the effect of $1.0 \mathrm{mM}$ (mucosal) furosemide on $\mathrm{Na}$ and $\mathrm{Cl}$ transport was examined. Figs. 3 and 4 display the results of individual experiments for $J_{\mathrm{Na}}^{\mathrm{ms}}$ and $J_{\mathrm{C}}^{\mathrm{ms}}$. These figures illustrate three important features: $(a)$ there was a large variability in the control rates of transport; $(b)$ only in bladders transporting at high rates was there any effect of furosemide; and $(c)$ in no bladder did furosemide inhibit the transport rate as completely as did ouabain and papaverine. In 12 of the bladders displayed in Figs. 3 and 4, the fluxes of $\mathrm{Na}$ and $\mathrm{Cl}$ were determined simultaneously and the mean values for these experiments are presented in Table III. The inhibition was greater on $J_{\mathrm{C}}^{\mathrm{ms}}\left(1.33 \pm 0.3 \mu \mathrm{M} / \mathrm{cm}^{2} \cdot \mathrm{h}\right)$ than on $J_{\mathrm{Na}}^{\mathrm{ms}}(0.70 \pm 0.28 \mu \mathrm{M} /$ $\left.\mathrm{cm}^{2} \cdot \mathrm{h}\right)$ by paired analysis.

The effect of bumetanide ( $0.1 \mathrm{mM}$ in the mucosal solution), a more potent inhibitor than furosemide in some tissues, was
Table II. Effect of Increasing Mucosal K Concentration on $J_{\mathrm{Cl}}^{\mathrm{ms}}$ and $\mathrm{J}_{\mathrm{Na}}^{\mathrm{ms}}$

\begin{tabular}{|c|c|c|c|c|c|}
\hline & \multicolumn{4}{|c|}{ Mucosal $[\mathrm{K}](m M)$} & \multirow{2}{*}{$\begin{array}{l}\text { Ouabain } \\
+ \text { papaverin }\end{array}$} \\
\hline & 0.02 & 0.07 & 0.56 & 1.05 & \\
\hline$J_{\mathrm{Na}}^{\mathrm{ms}}, \mu M / \mathrm{cm}^{2} \cdot h$ & 4.05 & 4.18 & 4.35 & 4.24 & $0.58^{*}$ \\
\hline$(n=7)$ & \pm 0.41 & \pm 0.36 & \pm 0.39 & \pm 0.32 & \pm 0.11 \\
\hline$J_{\mathrm{C}}^{\mathrm{ms}}, \mu M / \mathrm{cm}^{2} \cdot h$ & 3.61 & 3.80 & 3.77 & 3.85 & $1.71^{*}$ \\
\hline$(n=6)$ & \pm 0.47 & \pm 0.49 & \pm 0.51 & \pm 0.66 & \pm 0.18 \\
\hline
\end{tabular}

Mucosal [K] was increased sequentially and was measured at the end of each period. Short circuit current was 0 in all periods (because of the addition of mucosal $\left.\mathrm{Ba}^{++}\right) . G_{\mathrm{T}}$ was $0.569 \pm 0.094 \mathrm{mS} / \mathrm{cm}^{2}$ in the tissues where $J_{\mathrm{Na}}^{\mathrm{ms}}$ was measured and was $0.378 \pm 0.074 \mathrm{mS} / \mathrm{cm}^{2}$ in those where $J_{\mathrm{Cs}}^{\mathrm{ms}}$ was measured. These values did not change signifcantly after addition of $K$. Ouabain + papaverine values represent estimates of the backfluxes $\left(J_{\mathrm{Na}}^{\mathrm{sm}}\right.$ and $\left.J_{\mathrm{C}}^{\mathrm{sm}}\right)$ in these tissues.

* Value different from previously measured values.

examined in four bladders. In these bladders control $J_{\mathrm{Na}}^{\mathrm{ms}}$ was low $\left(1.32 \pm 0.19 \mu \mathrm{M} / \mathrm{cm}^{2} \cdot \mathrm{h}\right)$ and bumetanide had no effect $\left(1.31 \pm 0.18 \mu \mathrm{M} / \mathrm{cm}^{2} \cdot \mathrm{h}\right)$. Thus, it appears that bumetanide does not act differently than furosemide in this tissue.

Parallel $\mathrm{Na} / \mathrm{H}$ and $\mathrm{Cl} / \mathrm{OH}$ exchange. Coupled $\mathrm{Na}$ and $\mathrm{Cl}$ transport can occur by synchronous operation of parallel $\mathrm{Na} / \mathrm{H}$ and $\mathrm{Cl} / \mathrm{OH}$ exchangers. To examine whether these processes could explain $\mathrm{NaCl}$ absorption in this tissue, specific inhibitors were used. Amiloride has been shown to inhibit $\mathrm{Na} / \mathrm{H}$ exchange and is particularly effective when $\mathrm{Na}$ concentration is low (11). Table IV displays the results of experiments where $1 \mathrm{mM}$ amiloride was added to the mucosal solution containing $15 \mathrm{mM} \mathrm{Na}$ (choline replacement). There was no effect on $I_{\mathrm{sc}}$, $G_{\mathrm{T}}$, or $J_{\mathrm{Na}}^{\mathrm{ms}}$. Subsequent addition of ouabain and papaverine produced their usual effect. Table $\mathrm{V}$ displays the effect of 100 $\mu \mathrm{M}$ DIDS on $I_{\mathrm{sc}}, G_{\mathrm{T}}$, and $J_{\mathrm{C}}^{\mathrm{ms}}$. In these experiments, mucosal and serosal solutions were the modified Forster's solution. DIDS had no effect on any of the measured parameters. Subsequent

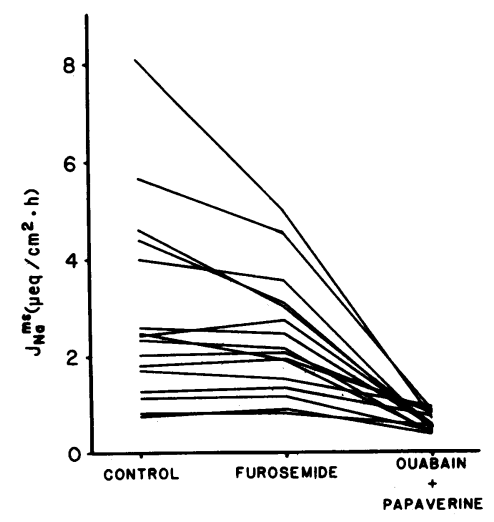

Figure 3. Effect of $1.0 \mathrm{mM}$ furosemide on $J_{\mathrm{Na}}^{\mathrm{ms}}$. Each line represents the mean of two 20 -min flux periods in a single tissue under the three conditions indicated on the abscissa. 


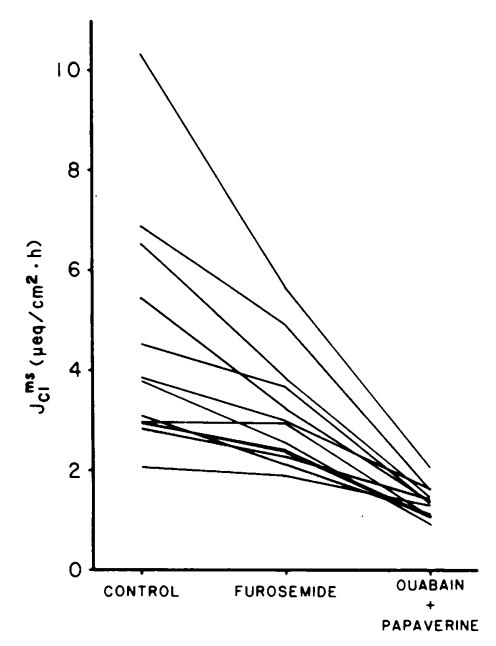

Figure 4. Effect of $1.0 \mathrm{mM}$ furosemide on $J_{\mathrm{Cl}}^{\mathrm{ms}}$. Experimental protocol as in Fig. 3. Some of the values displayed in this figure were determined simultaneously with some in Fig. 3. addition of ouabain and papaverine demonstrated the usual inhibition.

Although the lack of effect of amiloride and DIDS indicated that $\mathrm{NaCl}$ absorption was probably not via parallel exchangers, one additional experimental maneuver was attempted. Most epithelia that utilize this system contain carbonic anhydrase, the activity of which is critical for full operation of the cotransport system. Acetazolamide, a commonly used inhibitor of carbonic anhydrase, was added to both mucosal and serosal solutions to a concentration of $1.0 \mathrm{mM}$. There was no effect on $I_{\mathrm{sc}}, G_{\mathrm{T}}$, or $J_{\mathrm{Na}}^{\mathrm{ms}}$ in four tissues whereas ouabain and papaverine had their usual effect. Thus, these results are consistent with the notion that $\mathrm{NaCl}$ absorption does not occur by parallel exchangers.

Effects of thiazide diuretics. The effects of two members of the benzothiadiazide class of drugs were examined. The agents chosen were HCTZ and metolazone. The effect of $0.1 \mathrm{mM}$ HCTZ applied to the mucosal surface on $I_{\mathrm{sc}}$ and $G_{\mathrm{T}}$ is depicted in Fig. 5. HCTZ reduced $I_{\mathrm{sc}}$ (when present) to near 0 . The response began in 5-30 s and was usually complete within 2$3 \mathrm{~min}$. Washing out HCTZ produced a prompt return of $I_{\mathrm{sc}}$. Tissue conductance showed a similar time course. However, $G_{\mathrm{T}}$ consistently increased from a mean value of $0.541 \pm 0.091$

Table III. Effect of Furosemide on Simultaneously Determined $J_{N a}^{m s}$ and $J_{C l}^{m s}$

\begin{tabular}{lrcc}
\hline & Control & $\begin{array}{l}\text { Furosemide } \\
(1 \mathrm{mM})\end{array}$ & $\begin{array}{l}\text { Ouabain } \\
\text { + papaverine }\end{array}$ \\
\hline$J_{\mathrm{Na}}^{\mathrm{ms}}, \mu M / \mathrm{cm}^{2} \cdot h$ & 3.52 & $2.82^{*}$ & $0.63^{*}$ \\
& \pm 0.56 & \pm 0.30 & \pm 0.06 \\
$J_{\mathrm{Cl}}^{\mathrm{ms}}, \mu M / \mathrm{cm}^{2} \cdot h$ & 4.49 & $3.16^{*}$ & $\begin{array}{c}1.38^{*} \\
\end{array}$ \\
& \pm 0.70 & \pm 0.34 & \pm 0.08
\end{tabular}

* Significantly different from previous period $(n=12)$.
Table IV. Effect of Amiloride on $I_{s c}, G_{T}$, and $J_{N a}^{m s}$

\begin{tabular}{lccc}
\hline & Control & $\begin{array}{l}\text { Amiloride } \\
(1 \mathrm{mM})\end{array}$ & $\begin{array}{l}\text { Ouabain } \\
\text { + papaverine }\end{array}$ \\
\hline$I_{\mathrm{sc}}, \mu \mathrm{A} / \mathrm{cm}^{2}$ & 6.5 & 6.5 & $0.1^{*}$ \\
& \pm 1.8 & \pm 1.9 & \pm 0.1 \\
$G_{\mathrm{T}}, \mathrm{mS} / \mathrm{cm}^{2}$ & 0.786 & 0.718 & 0.543 \\
& \pm 0.088 & \pm 0.127 & \pm 0.120 \\
$J_{\mathrm{Na}}^{\mathrm{ms}}, \mu \mathrm{M} / \mathrm{cm}^{2} \cdot h$ & 3.30 & 3.28 & $0.42^{*}$ \\
& \pm 0.88 & \pm 0.90 & \pm 0.15
\end{tabular}

$\mathrm{Na}$ concentration of mucosal solution was $15 \mathrm{mM}$. Amiloride was added to mucosal solution.

* Value significantly different from control and amiloride values $(n=4)$.

$\mathrm{mS} / \mathrm{cm}^{2}$ to $0.791 \pm 0.128 \mathrm{mS} / \mathrm{cm}^{2}$. The time course for change in $G_{\mathrm{T}}$ was the same as that for $I_{\mathrm{sc}}$ and was readily reversible. In these same tissues, $J_{\mathrm{Na}}^{\mathrm{ms}}$ was measured and the results are displayed in Fig. 6. HCTZ inhibited the absorptive flux to values not different from those subsequently measured during ouabain and papaverine exposure. Thus, it appears that HCTZ completely inhibits net $\mathrm{Na}$ absorption.

The effect of $0.1 \mathrm{mM} \mathrm{HCTZ}$ applied to the serosal surface only was evaluated in four tissues. $J_{\mathrm{Na}}^{\mathrm{ms}}$ was unchanged $(2.06 \pm 0.72$ to $2.08 \pm 0.72 \mu \mathrm{M} / \mathrm{cm}^{2} \cdot \mathrm{h}$ ) as were $G_{\mathrm{T}}$ and $I_{\mathrm{sc}}$. Thus, HCTZ produces its characteristic effects only from the mucosal side.

The dose-response relationship for $I_{\mathrm{sc}}$ and $G_{\mathrm{T}}$ is displayed in Fig. 7. Tissues were used only if they displayed a spontaneous $I_{\mathrm{sc}}$. It is clear that there are dose-dependent changes in both parameters. The inhibition of $I_{\mathrm{sc}}$ in some tissues showed a transiently more negative value than did the steady-state value 5$10 \mathrm{~min}$ later. Although the reason(s) for this transient is (are) not clear, the effect of the drug was recorded at the peak response.

Table V. Effect of DIDS on $I_{s c}, G_{T}$, and $J_{C l}^{m s}$

\begin{tabular}{lccc}
\hline & Control & $\begin{array}{l}\text { DIDS } \\
(100 \mu \mathrm{M})\end{array}$ & $\begin{array}{l}\text { Ouabain } \\
+ \text { papaverine }\end{array}$ \\
\hline$I_{\mathrm{sc}}, \mu \mathrm{A} / \mathrm{cm}^{2}$ & 2.7 & 1.6 & $0.1^{*}$ \\
& \pm 1.4 & \pm 1.2 & \pm 0.1 \\
$G_{\mathrm{T}}, \mathrm{mS} / \mathrm{cm}^{2}$ & 0.429 & 0.479 & 0.404 \\
& \pm 0.075 & \pm 0.034 & 0.110 \\
$J_{\mathrm{CI}}^{\mathrm{ms}}, \mu \mathrm{M} / \mathrm{cm}^{2} \cdot h$ & 5.67 & 5.74 & $1.88^{*}$ \\
& \pm 0.98 & \pm 1.07 & \pm 0.42 \\
\hline
\end{tabular}

DIDS added to mucosal solution from stock solution in ethanol. Ethanol alone had no effect on these parameters.

* Value significantly different from control and DIDS values $(n=5)$. 

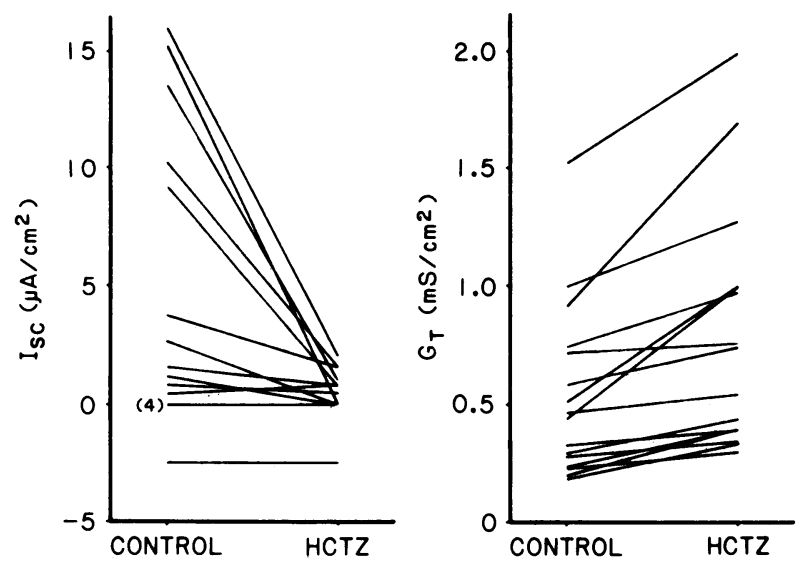

Figure 5. Effect of $0.1 \mathrm{mM}$ (mucosal) hydrochlorothiazide on $I_{\mathrm{sc}}$ and $G_{\mathrm{T}}$. Values are for individual bladders. Mean changes are statistically significant by paired analysis. (4) indicates four bladders in which $I_{\mathrm{sc}}$ $=0$ and did not change.

Thus, the slightly negative mean value for $I_{\mathrm{sc}}$ at $0.1 \mathrm{mM}$ reflects this transient. The fractional inhibition of $I_{\mathrm{sc}}$ at $10^{-6}, 10^{-5}$, and $10^{-4} \mathrm{M}$ was $0.06 \pm 0.03,0.38 \pm 0.10$, and (by definition) 1.00 . The fractional increase in $G_{\mathrm{T}}$ at these respective concentrations was $0.05 \pm 0.03,0.34 \pm 0.09$, and $0.63 \pm 0.13$. Although the data are not sufficient to conduct detailed kinetic analysis on the inhibitory effect, it is apparent that half-maximal inhibition of $I_{\mathrm{sc}}$ and half-maximal increase of $G_{\mathrm{T}}$ occurs at approximately $2-5 \times 10^{-5} \mathrm{M}$.

The effect of $0.1 \mathrm{mM} \mathrm{HCTZ}$ on simultaneously determined $\mathrm{Na}$ and $\mathrm{Cl}$ tracer fluxes is displayed in Table VI. Both $J_{\mathrm{Na}}^{\mathrm{ms}}$ and $J_{\mathrm{Cl}}^{\mathrm{ms}}$ were reduced but the reduction in $J_{\mathrm{CI}}^{\mathrm{ms}}$ was consistently (and significantly) greater than $J_{\mathrm{Na}}^{\mathrm{ms}}$. Mucosal HCTZ also reduced the

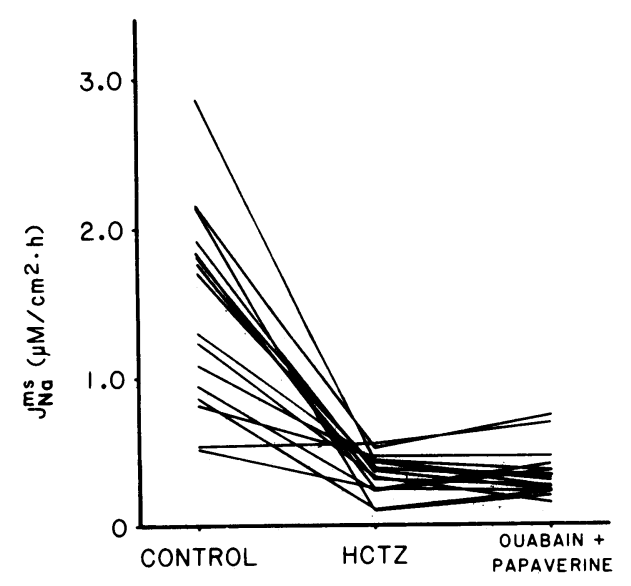

Figure 6. Effect of $0.1 \mathrm{mM}$ (mucosal) hydrochlorothiazide on $J_{\mathrm{Na}}^{\mathrm{ms}}$. Bladders are the same as depicted in Fig. 5. Reduction following HCTZ exposure is significant; subsequent exposure to ouabain and papaverine had no effect.

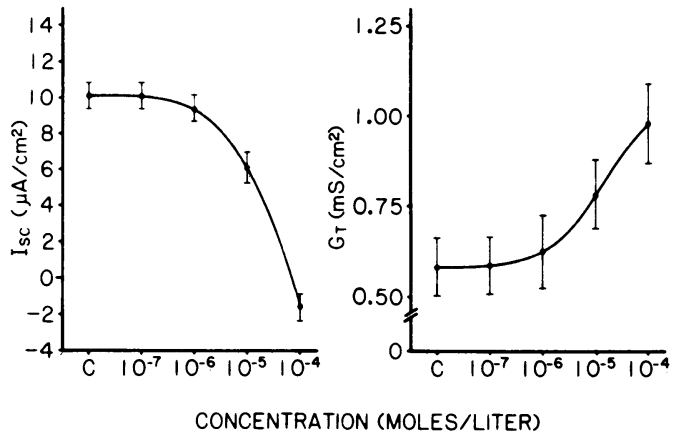

Figure 7. Dose-response relationship between HCTZ concentration (mucosal only) and peak response of $I_{\mathrm{sc}}$ and $G_{\mathrm{T}}(n=7)$. Curves drawn by inspection.

backflux (serosal-to-mucosal) of both $\mathrm{Na}$ and $\mathrm{Cl}$; this effect was also greater on $J_{\mathrm{Cl}}^{\mathrm{sm}}$ than on $J_{\mathrm{Na}}^{\mathrm{sm}}$. The net differences between the unidirectional fluxes, $J_{\mathrm{Na}}^{\text {net }}$ and $J_{\mathrm{Cl}}^{\text {net }}$, were not different in the control tissue, suggesting a 1:1 interdependence. After HCTZ, $J_{\mathrm{Cl}}^{\text {net }}$ was slightly larger than $J_{\mathrm{Na}}^{\text {net }}$ but it is not clear whether or not this difference represents a true differential effect on net $\mathrm{Na}$ and $\mathrm{Cl}$ fluxes or rather a variable effect of HCTZ on the backflux components.

The cellular mechanism of action of the thiazide diuretics is not known. One possibility is that they inhibit phosphodiesterase activity $(27,28)$. To evaluate the possible rate of cyclic AMP, six bladders were exposed to $1 \mathrm{mM}$ 8-Br-cAMP (both serosal and mucosal solutions). The results are displayed in Table VII. There were no changes in $J_{\mathrm{Na}}^{\mathrm{ms}}$ or in $I_{\mathrm{sc}}$ but $G_{\mathrm{T}}$ increased modestly.

Metolazone is a diuretic which is structurally dissimilar to the classic thiazide diuretics but which is usually included in this class of drugs because of its apparently similar mechanism of action (29). The time course of its effect on $I_{\mathrm{sc}}$ and $G_{\mathrm{T}}$ in two sections of the same bladder are displayed in Fig. 8. This figure illustrates several features regarding the effect of metolazone. First, in some tissues metolazone had a purely inhibitory effect on $I_{\mathrm{sc}}$ whereas in others there was a transient stimulatory effect. Second, the increase in $G_{\mathrm{T}}$ was seen in most tissues examined. Third, when there was an $I_{\mathrm{sc}}$ present, it was not completely reduced to 0 (as was the case for HCTZ). And fourth, the onset of action was substantially longer for metolazone than it was for HCTZ. Table VIII displays the effects on $I_{\mathrm{sc}}, G_{\mathrm{T}}$ and $J_{\mathrm{Na}}^{\mathrm{ms}}$ for eight tissues. Both $I_{\mathrm{sc}}$ and $J_{\mathrm{Na}}^{\mathrm{ms}}$ were inhibited but $I_{\mathrm{sc}}$ was further inhibited by ouabain and papaverine. In an additional four tissues, the effects of $0.1 \mathrm{mM}$ metolazone applied to the serosal solution were examined. There was no significant effect on $I_{\mathrm{sc}}, G_{\mathrm{T}}$, or $J_{\mathrm{Na}}^{\mathrm{ms}}$. Thus, the effects of metolazone were qualitatively similar to the effects of HCTZ and both acted only from the mucosal surface. The major difference relates to the longer time for metolazone to complete its actions, the occasional transient stimulation of the $I_{\mathrm{sc}}$, and quantitative differences in the magnitude of change in $I_{\mathrm{sc}}, J_{\mathrm{Na}}^{\mathrm{ms}}$, and $G_{\mathrm{T}}$. 
Table VI. Effect of HCTZ on Simultaneously Determined Na and Cl Tracer Fluxes

\begin{tabular}{|c|c|c|c|c|c|c|c|c|}
\hline & \multicolumn{8}{|l|}{ Flux } \\
\hline & \multicolumn{3}{|c|}{ Mucosa-to-serosa $(n=8)$} & \multicolumn{3}{|c|}{ Serosa-to-mucosa $(n=7)$} & \multicolumn{2}{|l|}{ Net } \\
\hline & $G_{\mathrm{T}}$ & $J J_{\mathrm{Na}}$ & $J_{\mathrm{c}}^{\mathrm{ma}}$ & $G_{\mathrm{T}}$ & $J_{\mathrm{Ne}}^{\mathrm{m}}$ & $J_{\mathrm{c}}^{\mathrm{mm}}$ & $J_{\mathrm{Na}}$ & $J_{\mathbf{c}}$ \\
\hline & $\mathrm{mS} / \mathrm{cm}^{2}$ & & & $\mathrm{mS} / \mathrm{cm}^{2}$ & & & & \\
\hline \multirow[t]{2}{*}{ Control } & 0.669 & 1.70 & 2.45 & 0.346 & 0.52 & 1.34 & 1.18 & 1.11 \\
\hline & \pm 0.147 & \pm 0.25 & \pm 0.30 & \pm 0.035 & \pm 0.07 & \pm 0.12 & & \\
\hline HCTZ & 0.951 & 0.40 & 0.69 & 0.665 & 0.23 & 0.29 & 0.17 & 0.40 \\
\hline$(0.1 \mathrm{mM})$ & \pm 0.186 & \pm 0.05 & \pm 0.24 & \pm 0.115 & \pm 0.02 & \pm 0.04 & & \\
\hline$P$ & $<0.01$ & $<0.005$ & $<0.005$ & $<0.02$ & $<0.002$ & $<0.001$ & - & - \\
\hline
\end{tabular}

$P$ value represents significance between control and HCTZ-treated group by paired analysis. Net fluxes are the differences between the mean unidirectional fluxes.

\section{Discussion}

The present results demonstrate some characteristics of electrically neutral $\mathrm{NaCl}$ absorption across a high resistance epithelium. Net $\mathrm{NaCl}$ transport involves an interdependence of $\mathrm{Na}$ and $\mathrm{Cl}$ but does not require mucosal $\mathrm{K}$. The process apparently does not involve synchronous parallel exchange of $\mathrm{Na}: \mathrm{H}$ and $\mathrm{Cl}: \mathrm{OH}$. An important feature which characterizes this system is its sensitivity to thiazide diuretics.

These results are generally consistent with results reported by others who have studied this epithelium. There is general agreement that the overall net rates of $\mathrm{Na}$ and $\mathrm{Cl}$ absorption are equal $(22,23$, and Table VI) and that there is codependency (22, and Figs. 1 and 2). The codependency portion of the transport appeared to be reasonably complete because at the lowest concentrations of $\mathrm{Na}$ or $\mathrm{Cl}$ examined, the coion flux was equal to or (in the case of $\mathrm{Cl}$ ) less than the backflux component estimated by subsequent treatment with ouabain and papaverine (Figs. 1 and 2). Renfro (22) has reported an incomplete reduction in net $\mathrm{Cl}$ absorption after removal of mucosal $\mathrm{Na}$ as well as

Table VII. Effect of $1 \mathrm{mM} 8$-Br-cAMP

\begin{tabular}{lrrl} 
& \multicolumn{1}{c}{$I_{\boldsymbol{c}}$} & \multicolumn{1}{l}{$G_{\mathrm{T}}$} & \multicolumn{1}{l}{$J_{\mathrm{Na}}^{\mathrm{m}}$} \\
\hline \multirow{3}{*}{ Control } & $\mu \mathrm{A} / \mathrm{cm}^{2}$ & \multicolumn{1}{c}{$\mathrm{mS} / \mathrm{cm}^{2}$} & $\mu M / \mathrm{cm}^{2} \cdot h$ \\
& 4.6 & 0.480 & 1.82 \\
& \pm 2.1 & \pm 0.094 & \pm 0.41 \\
8-Br-cAMP & 5.5 & 0.540 & 1.86 \\
& \pm 2.4 & \pm 0.102 & \pm 0.51 \\
$P$ & $\mathrm{NS}$ & $<0.05$ & $\mathrm{NS}$
\end{tabular}

8-Br-cAMP was added to both mucosal and serosal solutions. incomplete reduction in net $\mathrm{Na}$ absorption after removal of mucosal $\mathrm{Cl}$. It is not clear whether the residual fluxes were due to incomplete elimination of the coion (at the apical membrane) or whether there was a second transport mechanism(s) operating in parallel. One piece of evidence to favor the latter explanation is the observation that in those studies removal of $\mathrm{Cl}$ and amiloride had additive effects on $\mathrm{Na}$ transport. In the present studies, amiloride had no effect (Table IV).

As illustrated in Fig. 3, this tissue transports $\mathrm{NaCl}$ over a wide range of rates. The control transport rates appear to indicate the degree to which furosemide will inhibit transport. This partial (albeit modest) inhibition by high concentrations of furosemide
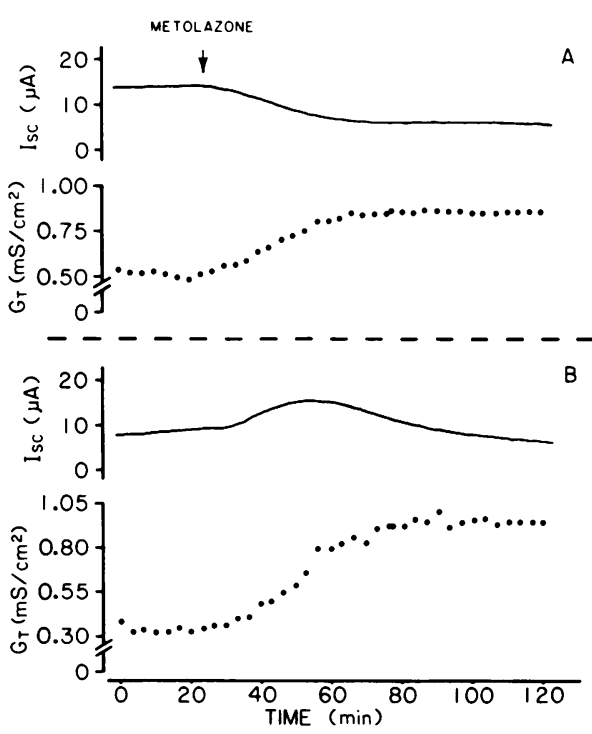

Figure 8. Effect of metolazone on $I_{\mathrm{sc}}$ and $G_{\mathrm{T}}$ on two sections of the same bladder. 
Table VIII. Effect of Metolazone on $I_{s c}, G_{T}$, and $J_{N a}^{m s}$

\begin{tabular}{lccc}
\hline & Control & $\begin{array}{l}\text { Metolazone } \\
(0.1 \mathrm{mM})\end{array}$ & $\begin{array}{l}\text { Ouabain } \\
\text { + papaverine }\end{array}$ \\
\hline$I_{\mathrm{sc}}, \mu \mathrm{A} / \mathrm{cm}_{2}$ & 6.6 & $2.6^{*}$ & $0.1^{*}$ \\
& \pm 1.6 & \pm 1.3 & \pm 0.1 \\
$G_{\mathrm{T}}, \mathrm{mS} / \mathrm{cm}^{2}$ & 0.490 & 0.714 & 0.500 \\
& \pm 0.090 & \pm 0.085 & \pm 0.094 \\
& 2.02 & $0.54^{*}$ & 0.39 \\
$J_{\mathrm{Na}}^{\mathrm{sm}}, \mu \mathrm{M} / \mathrm{cm}^{2} \cdot h$ & \pm 0.36 & \pm 0.06 & \pm 0.09
\end{tabular}

Metolazone added to mucosal solution $(n=8)$.

* Significantly different than previously measured value.

is consistent with Renfro's observation (21). The explanation for this partial inhibition is not certain but one of two possibilities seems likely: $(a)$ furosemide is a weak inhibitor of the system; or $(b)$ bladders with high rates of transport possess parallel systems only some of which are inhibited by furosemide. The bladders examined in the present experiments behaved as though they possessed a single mechanism of $\mathrm{NaCl}$ absorption. Efforts to reveal characteristics of parallel $\mathrm{Na} / \mathrm{H}$ and $\mathrm{Cl} / \mathrm{OH}$ exchange were completely negative. High concentrations of amiloride had no effect on $J_{\mathrm{Na}}^{\mathrm{ms}}$ despite the fact that the $\mathrm{Na}$ concentration in the mucosal solution was sufficiently low so that an effect should have been detected (11). The complete absence of an effect of DIDS (Table V) and acetazolamide support this conclusion.

Our understanding of the nature of $\mathrm{NaCl}$ cotransport is evolving rapidly. It was only recently believed that furosemide inhibited a (1:1) $\mathrm{NaCl}$ entry mechanism in a variety of epithelia (2). There is increasing evidence that furosemide-sensitive $\mathrm{NaCl}$ cotransport also requires $\mathrm{K}$ so that the $\mathrm{Na}: \mathrm{K}: \mathrm{Cl}$ coupling ratio is $1: 1: 2$ (4). Such a mechanism likely exists in the thick ascending limb of Henle's loop (5-7) as well as the shark rectal gland (26) and the intestine of the winter flounder (8). The lack of effect of increasing mucosal $\mathrm{K}$ concentration (Table II) on $\mathrm{Na}$ and $\mathrm{Cl}$ absorptive fluxes virtually eliminates the possibility that this entry mechanism was present in these flounder bladders.

The sensitivity of this absorptive mechanism to thiazide diuretics (especially HCTZ) further characterizes its unique features. These agents have been in clinical use for many years but astonishingly little is known about their cellular mechanism of action. There is general agreement that the major renal tubular segment on which they act is the distal convoluted tubule (3033). There is also an effect on the medullary collecting duct (34). Thiazides and furosemide act similarly on distal tubule $\mathrm{Na}$ and $\mathrm{Cl}$ transport but it is not clear that separate transport systems are involved. Both furosemide and chlorothiazide hyperpolarize the basolateral membrane (32), but chlorothiazide appears more effective in inhibiting $\mathrm{NaCl}$ absorption (33).

The effects of thiazides have also been examined in salientian urinary bladders. Pendleton et al. (35) found that bendroflu- methiazide had a variety of effects in the toad bladder. They found that addition to the serosal solution caused a fall in $I_{\mathbf{s c}}$ and mucosa-to-serosa $\mathrm{Na}$ flux. In contrast, addition to the mucosal solution caused a modest stimulation of $I_{\text {sc }}$. Addition to both solutions caused a biphasic response. Marumo et al. (36) examined the effect of HCTZ in the frog bladder and found partial inhibition of $I_{\mathrm{sc}}$ after mucosal addition and no change in electrical properties after serosal addition. Thus, effects of thiazides on epithelia which have electrogenic $\mathrm{Na}$ absorption are not clearly understood.

The effects of HCTZ and metolazone uncover some notable characteristics of the passive transport and electrical properties of the flounder bladder. The sum of the partial ionic conductances of $\mathrm{Na}$ and $\mathrm{Cl}$, if they occur only through the junctional complexes via simple diffusion, should approximate $G_{\mathrm{T}}$ if the latter is also primarily a paracellular conductance. Under the conditions of no electrochemical gradients across the epithelium (i.e., identical bathing solutions and no transepithelial voltage) the partial ionic conductance $\left(g_{\mathrm{i}}, \mathrm{mS} / \mathrm{cm}^{2}\right)$ is calculated by the following expression (37): $g_{\mathrm{i}}=J_{\mathrm{i}}\left(z^{2} F^{2}\right) /(R T)$, where $J_{\mathrm{i}}$ is the unidirectional flux, $z$ the valence of the ion, $F$ Faraday's constant, $R$ the gas constant, and $T$ the absolute temperature. Conveniently, under the present experimental conditions $g_{\mathrm{i}}=1.04 J_{\mathrm{i}}$ where $J_{\mathrm{i}}$ is the serosal-to-mucosal tracer flux (in $\mu \mathrm{M} / \mathrm{cm}^{2} \cdot \mathrm{h}$ ). Thus, the sum of the partial ionic conductances can be compared readily with $G_{\mathrm{T}}$ measured in the same tissue. From Table VI it is clear that in the control period the sum of the partial ionic conductances of $\mathrm{Na}$ and $\mathrm{Cl}$ were greater than $G_{\mathrm{T}}$, whereas the post-thiazide data show that $\left(g_{\mathrm{Na}}+g_{\mathrm{Cl}}\right)$ were not different than $G_{\mathrm{T}}$. Although it is not clear that in the thiazide-treated tissues these values are equal because they share the same conductive pathways, it is clear that in the untreated tissues some of the tracer flux occurs through pathways, which are electrically silent. The reduction of $J_{\mathrm{Na}}^{\mathrm{sm}}$ and $J_{\mathrm{C}}^{\mathrm{sm}}$ by mucosal exposure to $\mathrm{HCTZ}$ strongly suggests that these neutral pathways are through the cell. Furthermore, the mechanism whereby HCTZ inhibits the absorptive flux may be the same as that causing the inhibition of the backflux. A straightforward analysis of this data leads me to suspect that $\mathrm{HCTZ}$ inhibits a $\mathrm{NaCl}$ cotransporter located on the apical membrane through which active absorption occurs and through which a portion of the $\mathrm{Na}$ and $\mathrm{Cl}$ backflux also occurs. In this model the cotransporter would effect some $\mathrm{Na}$ and $\mathrm{Cl}$ exchange diffusion under normal operating circumstances. In support of the notion that a portion of the $\mathrm{Cl}$ backflux occurs via an apical $\mathrm{NaCl}$ cotransporter is the observation that in the absence of mucosal $\mathrm{Na} J_{\mathrm{Cl}}^{\mathrm{ms}}$ was significantly smaller than $J_{\mathrm{C}}^{\mathrm{ms}}$ in the same tissues exposed to ouabain and papaverine with $\mathrm{Na}$ present in the mucosal solution (Fig. 2).

The mechanism(s) underlying the effects of HCTZ on the electrical parameters is (are) not immediately obvious. The combination of reductions in $I_{\mathrm{sc}}$ and active transport together with an increase in $G_{\mathrm{T}}$ is unusual. A reasonable explanation for these results might be as follows. The $I_{\mathrm{sc}}$ is owing entirely to the secretion of $\mathrm{K}$ across the apical membrane (25). Although $\mathrm{K}$ secretion can be dissociated from $\mathrm{NaCl}$ absorption (for ex- 
ample, by addition of barium to the mucosal solution), the $I_{\mathrm{sc}}$ is dependent on $\mathrm{Na}(\mathrm{Cl})$ absorption so that $\mathrm{K}$ can enter the cell via the $\mathrm{Na}-\mathrm{K}$ pump. Elimination of $\mathrm{Na}$ absorption will thus stop $\mathrm{K}$ secretion and the $I_{\mathrm{sc}}$. The increase in $G_{\mathrm{T}}$ may be owing to a secondary effect to increase the (conductive) $\mathrm{K}$ permeability of the apical membrane. Although the reason for this (secondary) effect is unknown, there is precedent for increased apical $\mathrm{K}$ permeability after inhibition of $\mathrm{Na}$ entry across the apical membrane of other transporting epithelia $(38,39)$. This scenario might explain the transient increase in $I_{\mathrm{sc}}$ seen after metolazone. If the reduction in $\mathrm{Na}$ absorption was not sufficiently complete to reduce $\mathrm{K}$ entry via the pump below the secretory rate, then the (secondary) increase in apical $\mathrm{K}$ permeability might be expected to result in at least a transient rise in $I_{\mathrm{sc}}$. Whether or not this explanation for these observations is correct will require additional experimentation.

This transport system probably exists in the mammalian kidney. The clinical efficacy of thiazide diuretics supports the notion that this system occurs in man. It is probably confined to the distal convoluted tubule (30-33) (and perhaps the medullary collecting tubule, reference 34 ) since recent evidence indicates that there is no thiazide-sensitive $\mathrm{NaCl}$ absorption in the cortical thick ascending limb of Henle's loop where furosemide completely inhibits transport (40). The conclusion that furosemide and thiazides inhibit two different $\mathrm{Na}(\mathrm{Cl})$ transport systems in man is supported by the reports demonstrating additive effects of these classes of diuretics $(41,42)$.

In summary, the urinary bladder of the winter flounder has a $\mathrm{NaCl}$ absorption system which operates in the absence of transepithelial electrical activity. The mechanism of this absorptive process does not appear to involve $\mathrm{Na} / \mathrm{K} / \mathrm{Cl}$ cotransport nor parallel $\mathrm{Na} / \mathrm{H}$ and $\mathrm{Cl} / \mathrm{OH}$ exchange. Rather, it appears that the mechanism involves a simple $\mathrm{NaCl}$ cotransport process most likely located on the apical (luminal) membrane. This system is inhibited rapidly and reversibly by hydrochlorothiazide which acts only from the mucosal surface. Metolazone behaves in a qualitatively similar fashion but with a longer time course. The flounder bladder may be a useful model for $\mathrm{NaCl}$ absorption by the distal renal tubule.

\section{Acknowledgments}

I appreciate the encouragement and advice from Dr. David Dawson and David Andrew, and the critical review of the manuscript by Dr. Russell Husted and Dr. Michael Welsh. Ms. Syd Harned provided secretarial assistance.

This study was supported in part by National Institutes of Health grant AM-25231.

\section{References}

1. Warnock, D. G., and J. Eveloff. 1982. $\mathrm{NaCl}$ entry mechanisms in the luminal membrane of the renal tubule. Am. J. Physiol. 242(Renal Fluid Electrolyte Physiol. 11):F561-F574.

2. Frizzell, R. A., M. Field, and S. G. Schultz. 1979. Sodium-coupled chloride transport by epithelial tissues. Am. J. Physiol. 236(Renal Fluid and Electrolyte Physiol. 5):F1-F8.

3. Kirschner, L. B. 1983. Sodium chloride absorption across the body surface: frog skins and other epithelia. Am. J. Physiol. 244(Regulatory Integrative Comp Physiol. 13):R429-R443.

4. Geck, P., C. Pietrzyk, B. C. Burckhardt, B. Pfeiffer, and E. Heinz. 1980. Electrically silent cotransport of $\mathrm{Na}^{+}, \mathrm{K}^{+}$, and $\mathrm{Cl}^{-}$in Ehrlich cells. Biochim. Biophys. Acta. 600:432-447.

5. Greger, R., and E. Schlatter. 1981. Presence of luminal $\mathrm{K}^{+}$, a prerequisite for active $\mathrm{NaCl}$ transport in the cortical thick ascending limb of Henle's loop of rabbit kidney. Pflugers Arch. Eur. J. Physiol. 392:92-94.

6. Greger, R., E. Schlatter, and F. Lang. 1983. Evidence for electroneutral sodium chloride cotransport in the cortical thick ascending limb of Henle's loop of rabbit kidney. Pflugers Arch. Eur. J. Physiol. 396:308-314.

7. Greger, R., and E. Schlatter. 1983. Properties of the basolateral membrane of the cortical thick ascending limb of Henle's loop of rabbit kidney: a model for secondary active chloride transport. Pflugers Arch. Eur. J. Physiol. 396:325-334.

8. Musch, M. W., S. A. Orellana, L. S. Kimberg, M. Field, D. R. Halm, E. J. Krasny, Jr., and R. A. Frizzell. 1982. $\mathrm{Na}^{+}-\mathrm{K}^{+}-\mathrm{Cl}^{-}$cotransport in the intestine of a marine teleost. Nature (Lond.). 300:351-353.

9. Oberleithner, H., W. Guggino, and G. Giebisch. 1983. The effect of furosemide on luminal sodium, chloride and potassium transport in the early distal tubule of Amphiuma kidney. Effects of potassium adaptation. Pflugers Arch. Eur. J. Physiol. 396:27-33.

10. Oberleithner, H., F. Lang, R. Greger, W. Wang, and G. Giebisch. 1983. Effect of luminal potassium on cellular sodium activity in the early distal tubule of Amphiuma kidney. Pflugers Arch. Eur. J. Physiol. 396:34-40.

11. Kinsella, J. L., and P. S. Aronson. 1981. Amiloride inhibition of the $\mathrm{Na}^{+}-\mathrm{H}^{+}$exchanger in renal microvillus membrane vesicles. $A m$. J. Physiol. 10:F374-F379.

12. Cabantchik, Z. I., and A. Rothstein. 1972. The nature of the membrane sites controlling anion permeability of human red blood cells as determined by studies with disulfonic stilbene derivatives. J. Membr. Biol. 10:311-330.

13. Liedtke, C. M., and U. Hopfer. 1982. Mechanism of $\mathrm{Cl}^{-}$translocation across small intestinal brush border membrane. II. Demonstration of $\mathrm{Cl}^{-}-\mathrm{OH}^{-}$exchange and $\mathrm{Cl}^{-}$conductance. Am. J. Physiol. 242(Gastrointest. Liver Physiol. 5):G272-G280.

14. Liedtke, C. M., and U. Hopfer. 1982. Mechanism of $\mathrm{Cl}^{-}$translocation across small intestinal brush border membrane. I. Absence of $\mathrm{Na}^{+}-\mathrm{Cl}^{-}$cotransport. Am. J. Physiol. 242(Gastrointest. Liver Physiol. 5):G263-G271.

15. Fan, C., R. G. Faust, and D. W. Powell. 1983. Coupled sodiumchloride transport by rabbit ileal brush-border membrane vesicles. Am. J. Physiol. 244(Gastrointest. Liver Physiol. 7):G375-G385.

16. Friedman, P. A., and T. E. Andreoli. 1982. $\mathrm{CO}_{2}$-stimulated $\mathrm{NaCl}$ absorption in the mouse renal cortical thick ascending limb of Henle: evidence for synchronous $\mathrm{Na}^{+} / \mathrm{H}^{+}$and $\mathrm{Cl}^{-} / \mathrm{HCO}_{3}^{-}$exchange in apical plasma membranes. J. Gen. Physiol. 80:683-711.

17. Kinsella, J. L., and P. S. Aronson. 1980. Properties of the $\mathrm{Na}^{+}$$\mathrm{H}^{+}$exchanger in renal microvillus membrane vesicles. Am. J. Physiol. 238(Renal Fluid Electrolyte Physiol. 7):F461-F469.

18. Warnock, D. G., and V. J. Yee. 1981. Chloride uptake by brush border membrane vesicles isolated from rabbit renal cortex: coupling to proton gradients and $\mathrm{K}^{+}$diffusion potentials. J. Clin. Invest. 67:103115. 
19. Warnock, D. G., W. W. Reenstra, and V. J. Yee. 1982. $\mathrm{Na}^{+} /$ $\mathrm{H}^{+}$antiporter of brush border vesicles: studies with acridine orange uptake. Am. J. Physiol. 242(Renal Fluid Electrolyte Physiol. 11):F733F739.

20. Ericson, A., and K. R. Spring. 1982. Coupled $\mathrm{NaCl}$ entry into Necturus gallbladder epithelial cells. Am. J. Physiol. 243(Cell Physiol. 12):C140-C145.

21. Renfro, J. L. 1975. Water and ion transport by the urinary bladder of the teleost Pseudopleuronectes americanus. Am. J. Physiol. 228:52-61.

22. Renfro, J. L. 1978. Interdependence of active $\mathrm{Na}^{+}$and $\mathrm{Cl}^{-}$transport by the isolated urinary bladder of the teleost, Pseudopleuronectus americanus. J. Exp. Zool. 199:383-390.

23. Dawson, D. C., and D. Andrew. 1979. Differential inhibition of $\mathrm{NaCl}$ absorption and short-circuit current in the urinary bladder of the winter flounder, Pseudopleuronectes americanus. Bull. Mt. Desert Isl. Biol. Lab. 19:46-49.

24. Fossat, B., and B. Lahlou. 1979. The mechanism of coupled transport of sodium and chloride in isolated urinary bladder of the trout. J. Physiol. (Lond.). 294:211-222.

25. Dawson, D. C., and D. Andrew. 1980. Active potassium secretion by flounder urinary bladder: role of a basolateral Na-K pump and apical potassium channel. Bull. Mt. Desert Isl. Biol. Lab. 20:89-92.

26. Hannafin, J., E. Kinne-Saffran, D. Friedman, and R. Kinne. 1983. Ion fluxes and furosemide binding in rectal gland plasma membrane vesicles; evidence for the presence of a $\mathrm{Na}, \mathrm{K}, \mathrm{Cl}$ cotransport system. Kidney Int. 23:257. (Abstr.)

27. Moore, P. F. 1968. The effects of diazoxide and benzothiadiazine diuretics upon phosphodiesterase. Ann. NY Acad. Sci. 150:256-260.

28. Vulliemoz, Y., M. Verosky, and L. Triner. 1980. Effect of benzothiadiazine derivatives on cyclic nucleotide phosphodiesterase and on the tension of the aortic strip. Blood Vessels. 17:91-103.

29. Gilman, A. G., L. S. Goodman, and A. Gilman, editors. 1980. The Pharmacological Basis of Therapeutics. MacMillan Publishing Co., New York. 899-903.

30. Kunau, R. T., Jr., D. R. Weller, and H. L. Webb. 1975. Clar- ification of the site of action of chlorothiazide in the rat nephron. $J$. Clin. Invest. 56:401-407.

31. Costanzo, L. S., and E. E. Windhager. 1978. Calcium and sodium transport by the distal convoluted tubule of the rat. Am. J. Physiol. 235(Renal Fluid Electrolyte Physiol. 4):F492-F506.

32. Hansen, L. L., A. R. Schilling, and M. Wiederholt. 1981. Effect of calcium, furosemide, and chlorothiazide on net volume reabsorption and basolateral membrane potential of the distal tubule. Pflugers Arch. Eur. J. Physiol. 389:121-126.

33. Velazquez, H., and F. S. Wright. 1983. Renal distal tubule pathways for sodium, chloride, and potassium transport assessed by diuretics. Kidney Int. 23:269. (Abstr.)

34. Wilson, D. R., U. Honrath, and H. Sonnenberg. 1983. Thiazide diuretic effect on medullary collecting duct function in the rat. Kidney Int. 23:711-716.

35. Pendleton, R. G., L. P. Sullivan, J. M. Tucker, and T. E. Stephenson III. 1968. The effect of a benzothiadiazide on the isolated toad bladder. J. Pharmacol. Exp. Ther. 164:348-361.

36. Marumo, F., T. Mishina, and H. Shimada. 1982. Effects of diazoxide and hydrochlorothiazide on water permeability and sodium transport in the frog bladder. Pharmacology. 24:175-180.

37. Schultz, S. G. 1980. Basic Principles of Membrane Transport. Cambridge University Press, New York. 119.

38. Nagel, W., and W. Hirschmann. 1980. $\mathrm{K}^{+}$-permeability of the outer border of the frog skin (R. temporaria). J. Membr. Biol. 52:107113.

39. Halm, D., E. Krasny, and R. Frizzell. 1981. Apical membrane potassium conductance in flounder intestine: relation to chloride absorption. Bull. Mt. Desert Biol. Lab. 21:88-93.

40. Schlatter, E., R. Greger, and C. Weidtke. 1983. Effect of 'high ceiling' diuretics on active salt transport in the cortical thick ascending limb of Henle's loop of rabbit kidney: correlation of chemical structure and inhibitory potency. Pflugers Arch. Eur. J. Physiol. 396:210-217.

41. Ghose, R. R., and S. K. Gupta. 1981. Synergistic action of metolazone with 'loop' diuretics. Br. Med. J. 282:1432-1433.

42. Wollam, G. L., R. C. Tarazi, E. L. Bravo, and H. P. Dustan. 1982. Diuretic potency of combined hydrochlorothiazide and furosemide therapy in patients with azotemia. Am. J. Med. 72:929-938. 